ORIGINAL ARTICLE

\title{
Naloxone for narcotic exposed newborn infants: systematic review
}

\section{W McGuire, P W Fowlie}

Arch Dis Child Fetal Neonatal Ed 2003;88:F308-F311

See end of article for authors' affiliations

......................

Correspondence to: Dr McGuire, Tayside Institute of Child Health Ninewells Hospital and Medical School, Dundee DDI 9SY, Scotland, UK: w.mcguire@dundee.ac.uk

Accepted 3 September 2002
Background: Naloxone, a specific opiate antagonist, is available for the treatment of newborn infants with respiratory depression that may be due to transplacentally acquired opiates.

Aims: To determine if this treatment has any clinically important benefits, and whether there are any harmful effects.

Methods: Randomised controlled trials that compared naloxone with placebo or no drug for newborn infants with transplacental exposure to narcotics were systematically reviewed. The Cochrane Controlled Trials Register (CCTR; 2002, Issue 3), Medline (1966 to June 2002), and Embase (1988 to June 2002) were searched. Data were extracted, analysed, and synthesised using the standard methods of the Cochrane Neonatal Collaborative Review Group.

Results: Nine trials were found that fulfilled the specified inclusion criteria. Although there was evidence that naloxone increased alveolar ventilation, no data were found on the specified primary outcomes of this review: the need for assisted ventilation or admission to a neonatal unit.

Conclusions: There is a need for a randomised controlled trial to determine if naloxone confers any clinically important benefits on newborn infants with respiratory depression that may be due to transplacentally acquired narcotic.
T he International Liaison Committee on Resuscitation has provided guidance on the use of naloxone, a specific opiate antagonist, for the treatment of respiratory depression in narcotic exposed newborn infants. ${ }^{1}$ The advice follows the recommendation of the American Academy of Pediatrics Committee on Drugs that naloxone should not be used routinely in narcotic exposed newborn infants, but should be "reserved for adjunctive therapy in selected infants who have not initiated or established independent respiration following ventilation, are significantly depressed, and have a high probability of being narcotized". ${ }^{2}$ These recommendations refer to infants of mothers who have received opiate analgesia up to four hours before delivery. The dose recommended in 1980,
$0.01 \mathrm{mg} / \mathrm{kg}$ given intravenously or by an endotracheal route, was later revised to $0.1 \mathrm{mg} / \mathrm{kg}$. ${ }^{3}$

There is evidence that in current practice naloxone is administered to many more newborn infants than recommended by the American Academy of Pediatrics Committee on Drugs. ${ }^{4}$ Herschel and colleagues ${ }^{5-7}$ caution that naloxone should not be regarded as harmless, and cite concerns that naloxone may interfere with the role of endogenous opioids in neuroendocrine programming and affect behaviour. Given these questions of appropriateness of use and potential harm, we have undertaken a systematic review to evaluate the evidence of effect of naloxone on the need for respiratory support or admission to a neonatal unit in narcotic exposed newborn infants.

\begin{tabular}{|c|c|}
\hline Studies: & Randomised or quasi-randomised controlled trials \\
\hline Participants: & $\begin{array}{l}\text { Newborn infants, cared for in a hospital setting, with suspected or confirmed exposure to maternal narcotic analgesia } \\
\text { before delivery }\end{array}$ \\
\hline Interventions: & Naloxone versus placebo or no drug \\
\hline \multirow[t]{2}{*}{ Outcomes: } & $\begin{array}{l}\text { Primary: } \\
\text { 1. Assisted ventilation in the neonatal period } \\
\text { 2. Duration of assisted ventilation } \\
\text { 3. Admission to neonatal unit or special care baby unit } \\
\text { 4. Duration of neonatal unit or special care baby unit admission }\end{array}$ \\
\hline & $\begin{array}{l}\text { Secondary: } \\
\text { 1. Time to establish full oral feeds, independently of parenteral fluids or nutrition or of enteral tube feeding } \\
\text { 2. Features of opiate withdrawal; validated behavioural assessment in the neonatal period } \\
\text { 3. Seizures in the neonatal period } \\
\text { 4. Neurodevelopmental outcomes during infancy and beyond using validated assessment tools } \\
\text { 5. Measures of respiratory function, such as Apgar score, or arterial blood pH or arterial or alveolar carbon dioxide } \\
\text { tension measured within the first six hours of life }\end{array}$ \\
\hline Subgroup analyses: & $\begin{array}{l}\text { 1. Dose of naloxone }<0.1 \mathrm{mg} / \mathrm{kg} \text { body weight } \\
\text { 2. Dose of naloxone } \geqslant 0.1 \mathrm{mg} / \mathrm{kg}\end{array}$ \\
\hline
\end{tabular}


Table 2 Characteristics of included studies: participants, intervention, and outcomes

\begin{tabular}{|c|c|c|c|c|}
\hline Trial & Participants & Interventions & Outcomes & Notes \\
\hline Bonta $^{8}$ & $\begin{array}{l}43 \text { normal term newborn infants } \\
\text { whose mothers received narcotic } \\
\text { analgesia within six hours of } \\
\text { delivery. }\end{array}$ & $\begin{array}{l}\text { 1. Intramuscular naloxone }(0.02 \\
\mathrm{mg} / \mathrm{kg})(\mathrm{n}=22) \\
\text { 2. Placebo (saline) }(\mathrm{n}=21)\end{array}$ & $\begin{array}{l}\text { Apgar score at five minutes, } \\
\text { capillary blood gas values at } 1,2 \text {, } \\
\text { and } 4 \text { hours of life, } \\
\text { neurobehavioral assessment at } 1 \text {, } \\
4 \text {, and } 24 \text { hours. }\end{array}$ & $\begin{array}{l}\text { Infants delivered in breech } \\
\text { presentation or by caesarean } \\
\text { section, infants with Apgar score } \\
<6 \text { at one minute, were excluded }\end{array}$ \\
\hline Brice $^{9}$ & $\begin{array}{l}50 \text { term newborn infants whose } \\
\text { mothers received pethidine within } \\
\text { four hours of delivery. }\end{array}$ & $\begin{array}{l}\text { 1. Naloxone via umbilical vein } \\
\text { (0.01 or } 0.02 \mathrm{mg} / \mathrm{kg})(\mathrm{n}=26) \\
\text { 2. No drug }(\mathrm{n}=24)\end{array}$ & $\begin{array}{l}\text { Time to sustained respiration, } \\
\text { expired } \mathrm{CO}_{2} \text { output and alveolar } \\
\text { ventilation, Brazelton score and } \\
\text { Scanlon score within the first } 24 \\
\text { hours of life. }\end{array}$ & $\begin{array}{l}\text { Blinding of outcome measuremen } \\
\text { for Scanlon score only. }\end{array}$ \\
\hline $\operatorname{Dick}^{10}(a)$ & $\begin{array}{l}40 \text { newborn infants, of } \\
\text { unspecified gestation, whose } \\
\text { mothers had been given pethidine } \\
\text { in labour. }\end{array}$ & $\begin{array}{l}\text { 1. Naloxone via umbilical vein } \\
(0.02-0.04 \mathrm{mg} / \mathrm{kg})(\mathrm{n}=30) \\
\text { 2. No drug }(\mathrm{n}=10)\end{array}$ & $\begin{array}{l}\text { Capillary blood gas } \mathrm{pH} \text { and } \\
\text { partial pressure of } \mathrm{CO}_{2} \text { and of } \\
\text { oxygen at } 1,5,10,30,60 \text {, and } \\
120 \text { minutes of life. }\end{array}$ & $\begin{array}{l}\text { Presumed, although not stated } \\
\text { explicitly in the report, that } \\
\text { naloxone was administered at } \\
\text { birth. }\end{array}$ \\
\hline $\operatorname{Dick}^{10}(b)$ & $\begin{array}{l}30 \text { newborn infants, of } \\
\text { unspecified gestation, whose } \\
\text { mothers had been given pethidine } \\
\text { in labour. }\end{array}$ & $\begin{array}{l}\text { 1. Naloxone via umbilical vein } \\
\text { (either } 0.04 \mathrm{mg} / \mathrm{kg} \text { or } 0.04 \mathrm{mg} \\
\text { total) }(\mathrm{n}=10) \\
\text { 2. Placebo }(\mathrm{n}=20)\end{array}$ & $\begin{array}{l}\text { Capillary blood gas } \mathrm{pH} \text {, partial } \\
\text { pressure of } \mathrm{CO}_{2} \text { and of oxygen, } \\
\text { and calculated base excess at } 1 \text {, } \\
5,10,30,60 \text {, and } 120 \text { minutes } \\
\text { of life. }\end{array}$ & \\
\hline Evans ${ }^{11}$ & $\begin{array}{l}44 \text { newborn infants, of gestation } \\
38-42 \text { weeks, delivered vaginally, } \\
\text { whose mothers had been given } \\
\text { pethidine in labour. }\end{array}$ & $\begin{array}{l}\text { 1. Naloxone via umbilical vein } \\
\text { (0.04 mg total) }(n=20) \\
\text { 2. No drug }(n=24)\end{array}$ & $\begin{array}{l}\text { Time to first breath and onset of } \\
\text { sustained respiration, } \mathrm{Apgar} \text { score } \\
\text { at five minutes, alveolar } \mathrm{CO}_{2} \\
\text { tension, alveolar ventilation, and } \\
\text { ventilation rate at } 10 \text { and } 30 \\
\text { minutes of life. }\end{array}$ & $\begin{array}{l}\text { Apgar score, time to first breath } \\
\text { and to sustained respiration } \\
\text { reported as mean values, but } \\
\text { without standard deviations. }\end{array}$ \\
\hline Gerhardt $^{12}$ & $\begin{array}{l}20 \text { term newborn infants, whose } \\
\text { mothers received pethidine within } \\
\text { three hours before delivery. }\end{array}$ & $\begin{array}{l}\text { 1. Intramuscular naloxone }(0.01 \\
\mathrm{mg} / \mathrm{kg})(\mathrm{n}=12) \\
\text { 2. Placebo }(\mathrm{n}=8)\end{array}$ & $\begin{array}{l}\text { Respiratory rate, tidal volume, } \\
\text { minute ventilation, end-tidal } \mathrm{CO}_{2} \\
\text { tension, and response to } \\
\text { inhalation of } 4 \% \mathrm{CO}_{2} \text {. }\end{array}$ & $\begin{array}{l}\text { Only infants born vaginally were } \\
\text { eligible for inclusion. } \\
\text { Naloxone was given at } 30 \\
\text { minutes of age. }\end{array}$ \\
\hline Welles $^{13}$ & $\begin{array}{l}27 \text { newborn infants, of gestation } \\
38-42 \text { weeks, whose mothers } \\
\text { received pethidine during labour. }\end{array}$ & $\begin{array}{l}\text { 1. Intramuscular naloxone }(0.1 \mathrm{mg} \\
\text { total) }(\mathrm{n}=14) \\
\text { 2. Placebo (saline) }(\mathrm{n}=13)\end{array}$ & $\begin{array}{l}\text { Brazelton score at } 12-24 \text { hours of } \\
\text { life and after a further } 48 \text { hours. } \\
\text { Broussard neonatal perception } \\
\text { inventory at about } 72 \text { hours. }\end{array}$ & $\begin{array}{l}\text { Naloxone was given at one hour. } \\
\text { Infants with Apgar scores }<8 \text { at } \\
\text { one minute, or }<9 \text { at five minutes } \\
\text { were not eligible for inclusion. }\end{array}$ \\
\hline Wiener $^{14}$ & $\begin{array}{l}28 \text { newborn infants, of gestation } \\
38-42 \text { weeks, whose mothers had } \\
\text { been given pethidine in labour. }\end{array}$ & $\begin{array}{l}\text { 1. Naloxone via the umbilical vein } \\
(0.04 \mathrm{mg} \text { total) }(n=10) \\
\text { 2. Placebo (saline) }(n=18)\end{array}$ & $\begin{array}{l}\text { Alveolar } \mathrm{CO}_{2} \text { tension, } \mathrm{CO}_{2} \\
\text { excretion, alveolar ventilation, } \\
\text { feeding behaviour, and } \\
\text { habituation to a sound specific } \\
\text { stimulus up to } 48 \text { hours of life. }\end{array}$ & $\begin{array}{l}\text { Naloxone or normal saline were } \\
\text { "chosen blind at random". }\end{array}$ \\
\hline Wiener $^{15}$ & $\begin{array}{l}30 \text { newborn infants, of gestation } \\
38-42 \text { weeks, whose mothers had } \\
\text { been given pethidine in labour. }\end{array}$ & $\begin{array}{l}\text { 1. Intramuscular naloxone at one } \\
\text { minute of age }(0.2 \mathrm{mg} \text { total) } \\
\text { ( } \mathrm{n}=15) \\
\text { 2. Placebo (saline) }(\mathrm{n}=15)\end{array}$ & $\begin{array}{l}\text { Alveolar } \mathrm{CO}_{2} \text { tension, } \mathrm{CO}_{2} \\
\text { excretion, alveolar ventilation, } \\
\text { feeding behaviour, and } \\
\text { habituation to a sound specific } \\
\text { stimulus up to } 48 \text { hours. }\end{array}$ & \\
\hline
\end{tabular}

\section{METHODS}

We used the standard search strategy of the Neonatal Collaborative Review Group (http://cochrane.mcmaster.ca/neonatal/). This included electronic searches of the Cochrane Controlled Trials Register (CCTR; 2002, Issue 2), Medline (1966 to April 2002), and Embase (1988 to April 2002). We did not apply any language restriction. We examined references in studies identified as potentially relevant, and in previous reviews and textbooks of neonatal medicine. We asked the manufacturer of Narcan (DuPont Pharmaceuticals, Wilmington, Delaware, USA; 19880) to provide any data unavailable from other sources.

The search strategy involved the following keywords and MeSH subject headings: "Infant-Newborn"/all subheadings, infan*, neonat*, newborn, explode "naloxone"/all subheadings, naloxone, narcan, explode "naltrexone"/all subheadings, explode "narcotic antagonists"/all subheadings, narcotic near3 antagonist, opiate near3 antagonist.

The first reviewer screened the title and abstract of studies identified by the above search strategy. Both reviewers rescreened the full text of the report of each potentially relevant study. Only studies that met all of the specified criteria (table 1) were included. The reviewers resolved any disagreement by discussion.

We evaluated trial quality in terms of allocation concealment, blinding of parents, carers, and assessors to intervention, and completeness of assessment. We expressed the effects as weighted mean difference and 95\% confidence interval for continuous data, and used a fixed effect model for meta-analysis.

\section{RESULTS}

Overall, 11 studies that appeared to be relevant were identified in the first round of screening. ${ }^{8-17}$ DuPont Pharmaceuticals did not provide any further data than those already found from other sources. One study ${ }^{17}$ was excluded because it was not a randomised comparison. Another ${ }^{16}$ reported data that had been available in a previous publication ${ }^{15}$ by the same investigators. The other nine studies were included and these are detailed in table 2. Two of these studies were reported in the same article. ${ }^{10}$

All of the included studies were undertaken in the 1970s or early 1980s. These studies recruited term infants whose mothers had received pethidine (meperidine) for pain relief up to six hours before delivery. However, none of the included trials restricted entry to infants with respiratory depression following narcotic exposure. In four studies, naloxone was administered by the intramuscular route, and in the other five studies by the umbilical venous route. The dose of naloxone ranged from $0.01 \mathrm{mg} / \mathrm{kg}$ to $0.04 \mathrm{mg} / \mathrm{kg}$, except in one study ${ }^{15}$ in which a dose of $0.2 \mathrm{mg}$ (total) was given.

All of the trials were small (20-50 infants), and none presented a power or sample size calculation. Three studies achieved allocation concealment (blinding of randomisation). ${ }^{8}{ }^{14}{ }^{15}$ The carers or assessors were blind to the intervention in four studies. ${ }^{8} 101415$ The outcome assessors were blind to the intervention in five of the trials. ${ }^{8}{ }^{10}{ }^{13-15}$ All of the trials appear to have achieved complete or almost complete follow up of infants recruited, although none of the trials undertook follow up beyond the first three days of life. 
Study

Weighted mean difference $(95 \% \mathrm{Cl})$ at 30 minutes

$\begin{array}{ll}\text { Brice }^{9} & 11.0(-14.0 \text { to } 36.0) \\ \text { Evans }^{11} & 23.0(-8.0 \text { to } 54.0) \\ \text { Wiener }^{14} & 35.0(5.6 \text { to } 64.4) \\ \text { Wiener }^{15} & 81.0(52.4 \text { to } 109.6) \\ \text { Pooled } & 36.0(21.9 \text { to } 50.1)\end{array}$

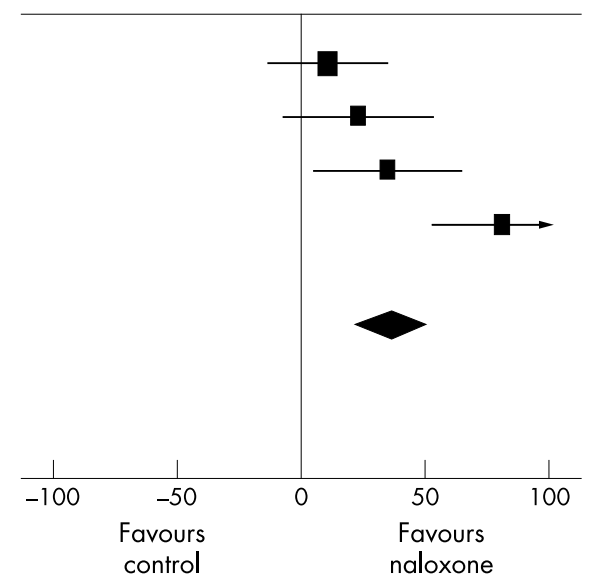

Weighted mean difference $(95 \% \mathrm{Cl})$ at 4 hours

Weight (\%)

100.0

Heterogeneity: $\mathrm{X}^{2}$ 14.0, $\mathrm{p}=0.003$
Figure 1 Effect of naloxone on the alveolar ventilation rate $(\mathrm{ml} / \mathrm{kg} / \mathrm{min})$. Cl, Confidence interval.

\section{Outcome data}

The included studies did not provide any data on either of the predefined primary outcomes of this review: assisted ventilation or admission to a neonatal unit.

With regard to secondary outcome measures, we did not find any data on time to establishment of oral feeding, seizures in the neonatal period, or neurodevelopmental outcomes. Five of the trials presented data on validated behavioural assessments in the neonatal period. ${ }^{89^{13-15}}$ The studies that reported the Scanlon behavioural score ${ }^{89}$ and the Brazelton neonatal behavioural assessment score ${ }^{913}$ did not find any significant differences. One trial reported the Broussard neonatal perception inventory at 72 hours and found significantly "less optimal behaviour" in the naloxone group. ${ }^{13}$ However, standard deviations were not reported in any of these studies, and meta-analyses were not possible.

Wiener $e t$ al $^{15}$ found that the time taken to habituate to a sound specific stimulus within the first 48 hours was significantly lower in infants who received intramuscular naloxone versus placebo. There were no significant differences between infants who received intravenous naloxone versus placebo. ${ }^{14}$

Eight of the trials presented data on measures of respiratory function within the first six hours of life. ${ }^{8-12} 14{ }^{15}$ There were no significant differences in the Apgar score, ${ }^{10}$ ventilation rate, ${ }^{11}$ minute ventilation, ${ }^{12}$ or blood gas parameters. ${ }^{8}{ }^{10}$ Four of these trials assessed measures of alveolar ventilation. ${ }^{911}{ }^{14} 15$ There was evidence that, 30 minutes and four hours after the intervention, the alveolar ventilation rate was significantly higher in the naloxone group (fig 1). There was significant heterogeneity in the meta-analysis of the 30 minute data, arising from one study. ${ }^{15}$ This study used a larger dose of naloxone, which was given intramuscularly compared with intravenously in the other studies. The differences in outcome may be due to differences in bioavailability of naloxone.
The planned subgroup analysis according to naloxone dose (less than, or equal to, or greater than $0.1 \mathrm{mg} / \mathrm{kg}$ body weight) could not be performed because we did not find any eligible trials using a naloxone dose in the higher range.

\section{DISCUSSION}

We have found nine trials that compared naloxone with placebo or no drug in newborn infants exposed to maternal narcotic analgesia before delivery. However, we did not find any data on clinically important outcomes such as the need for assisted ventilation or admission to a neonatal unit, the specified primary outcome measures for this review. The infants recruited to the trials did not appear to have had respiratory depression that required ventilatory support or admission to a neonatal unit. Although this is not stated explicitly in most of the reports, infants with low Apgar scores were not eligible for inclusion in two trials. ${ }^{813}$ Therefore the findings of the trials are of limited relevance in the clinical context for which naloxone is currently recommended by the American Academy of Pediatrics Committee on Drugs-that is, for infants with significant respiratory depression that is probably due to transplacentally acquired opiate. ${ }^{2}$

Infants who received naloxone had increased alveolar ventilation compared with control infants. However, the clinical significance of this finding is unclear. Similarly, although there is evidence from one study that naloxone reduced the time to habituate to an auditory stimulus, ${ }^{15}$ the clinical relevance of this finding is unknown. We did not find any data on clinically important neurological outcomes in the neonatal period or on any longer term outcomes.

There is a need for a randomised controlled trial to determine if naloxone confers any clinically important benefits on newborn infants with respiratory depression that 
may be due to transplacentally acquired narcotic. This trial should assess outcomes that are relevant to the infant, family, and carers, such as the need for assisted mechanical ventilation or admission to a neonatal unit. Given the concerns that naloxone may interfere with the role of endogenous opioids in neuroendocrine programming and on behaviour, ${ }^{5-7}$ follow up assessment beyond infancy will be required to determine neurodevelopmental outcomes.

\section{Authors' affiliations}

W McGuire, P W Fowlie, Tayside Institute of Child Health, Ninewells Hospital and Medical School, Dundee DDI 9SY, Scotland, UK

\section{REFERENCES}

1 Niermeyer S, Van Reempts P, Kattwinkel J, et al. Resuscitation of newborns. Ann Emerg Med 2001;37:S1 10-25.

2 American Academy of Pediatrics Committee on Drugs. Naloxone use in newborns. Pediatrics 1980;65:667-9.

3 American Academy of Pediatrics Committee on Drugs. Naloxone dosage and route of administration for infants and children: addendum to emergency drug doses for infants and children. Pediatrics 1990;86:484-5.

4 Herschel M, Khoshnood B, Lass NA. Role of naloxone in newborn resuscitation. Pediatrics 2000;106:831-4.

5 Smotherman WP, Robinson SR. Prenatal experience with milk: fetal behavior and endogenous opioid systems. Neurosci Biobehav Rev 1992;16:351-64.
6 de Castro RM, Cabral-Filho JE, Costa JA, et al. Neonatal treatment with naloxone causes permanent hyperalgesia in rats. Braz J Med Biol Res 1993;26:747-51.

7 Szeto $\mathbf{H H}$, Soong Y, Wu DL, et al. Opioid modulation of fetal glucose homeostasis: role of receptor subtypes. J Pharmacol Exp Ther 1995:275:334-9.

8 Bonta BW, Gagliardi JV, Williams V, et al. Naloxone reversal of mild neurobehavioral depression in normal newborn infants after routine obstetric analgesia. J Pediatr 1979;94:102-5

9 Brice JE, Moreland TA, Walker CH. Effects of pethidine and its antagonists on the newborn. Arch Dis Child 1979;54:356-61.

10 Dick W, Knoche E, Traub E. Clinical investigations of the influence of various naloxone doses on the newborn. J Perinat Med 1978;6:95-101.

11 Evans JM, Hogg MI, Rosen M. Reversal of narcotic depression in the neonate by naloxone. BM 1976;2:1098-100.

12 Gerhardt T, Bancalari E, Cohen H, et al. Use of naloxone to reverse narcotic respiratory depression in the newborn. J Pediatr 1977:90:1009-12.

13 Welles B, Belfrage $P$, de Chateau P. Effects of naloxone on newborn infant behavior after maternal analgesia with pethidine during labor. Acta Obstet Gynecol Scand 1984;63:617-19.

14 Wiener PC, Hogg MI, Rosen M. Effects of naloxone on pethidine-induced neonatal depression. Part 1. Intravenous naloxone. BM 1977;2:228-9.

15 Wiener PC, Hogg MI, Rosen M. Effects of naloxone on pethidine-induced neonatal depression. Part 2. Intramuscular naloxone. BM 1977;2:229-31.

16 Weiner PC, Hogg MI, Rosen M. Neonatal respiration, feeding and neurobehavioural state. Effects of intrapartum bupivacaine, pethidine and pethidine reversed by naloxone. Anaesthesia 1979;34:996-1004.

17 Brice JEH, Moreland TA, Parija AC, et al. Plasma naloxone levels in the newborn after intravenous or intramuscular administration. Br J Clin Pharmacol 1979;8:412P-13P.

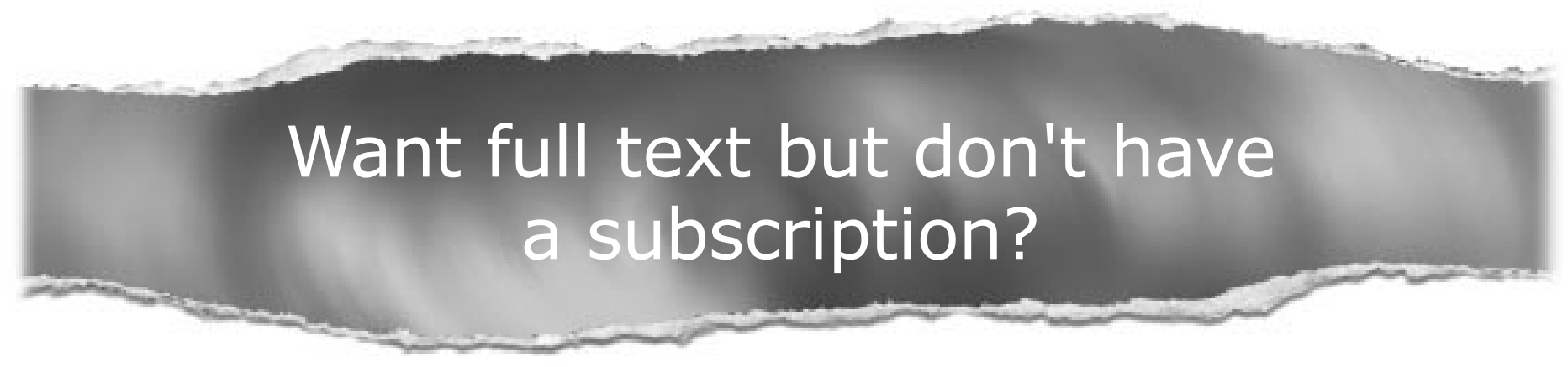

\section{Pay per view}

For just $\$ 8$ you can purchase the full text of individual articles using our secure online ordering service. You will have access to the full text of the relevant article for 48 hours during which time you may download and print the pdf file for personal use.

www.archdischild.com 